\title{
South African Railways postcard calendars, 1961 to 1984
}

\author{
Jeanne van Eeden* \\ University of Pretoria \\ *Email: jeanne.vaneeden@up.ac.za
}

\begin{abstract}
This article focuses on a series of postcard calendars produced by the South African Railways (SAR) between 1961 and 1984. As a state-owned organisation, the SAR played a decisive role in conceptualising the metanarratives South Africa constructed of itself from 1910 onwards. This was achieved, for example, through an extensive visual archive of documentary photographs of South Africa, commissioned by the SAR. In addition to a range of 'publicity propaganda' material, from about the 1920s to 1984 the Publicity Department of the SAR intermittently produced postcards, calendars and postcard calendars as cheap and accessible promotional material. An analysis of the postcard calendars between 1961 and 1984uncovers three thematic clusters: the natural world; the world of culture; and related to this, the world of technology, modernity and progress. In colonialist discourse, images of nature/‘primitivism’ were frequently offset by images that proclaimed the advantages of culture/modernity/technology, and this legacy manifests in the postcard calendars discussed in this article. The article suggests that the SAR had vested interests in how (white), middle-class South Africans imagined the country and how it was portrayed for international audiences.
\end{abstract}

Keywords: postcards; national identity; propaganda; South Africa; tourism

\section{Introduction}

From the 1920s to about 1984, the Publicity Department of the South African Railways (now Transnet) intermittently produced postcards, pictorial calendars and postcard calendars that were used to encourage tourism, both nationally and internationally. As a state-owned organisation, 
the South African Railways (hereafter SAR) played a considerable role in establishing patterns of travel and tourism that were part of the broader discourse of how South Africa represented itself. Although postcards have only recently started to become objects of serious study, it has been recognized that because they are accessible, portable and affordable products of popular culture, they play an important part in the circuit of culture ${ }^{1}$ that helps construct narratives such as nationhood. The SAR generated an enormous amount of publicity material from 1910 onwards that, in conjunction with state-sponsored journals such as Lantern and Panorama ${ }^{2}$ and bodies such as the South African Tourist Corporation (Satour), created a propagandistic discourse about South Africa.

In this article, I focus on the postcard calendars that were produced by the SAR between 1961 and 1984, a period when tourism in apartheid South Africa was the almost exclusive domain of 'white elite culture'. ${ }^{3}$ What made these calendars unique was their format, which comprised a calendar consisting of 24 sheets, two for each month, with the postcard on the top half and the calendar on the bottom. The sheets were perforated, allowing the postcards to be 'detached after the lapse of the dates on the lower portion'4 (fig 1). These postcard calendars were widely

\footnotetext{
${ }^{1}$ S. Hall, ed., Representation. Cultural Representations and Signifying Practices (London, Sage, 1997).

${ }^{2}$ Lantern was published between 1951 and 1994, whilst Panorama started in 1956 and ended in 1992. See L.

Groenewald, 'Cloudless Skies Versus Vitamins of the Mind: An Argumentative Interrogation of the Visual Rhetoric of South African Panorama and Lantern Cover Designs (1949-1961)', Image \& Text, 20 (2012), 50-86.

${ }^{3}$ G. Visser and C.M.Rogerson, 'Researching the South African Tourism and Development Nexus', GeoJournal, 60 (2004), 201.

${ }^{4}$ Transnet Heritage Library, Johannesburg (hereafter THL), SAR Departmental Reports Submitted in Connection with the Preparation of the General Manager's Report for 1960-1961, 18. The depiction of dual modes of transport in this image, namely road and rail, was an important trope in the manner in which the SAR was publicized, for example in the paintings by C.E. Turner for the Illustrated London News ('Rail, Road and Air Travel Through the Varied Scenery of South Africa: the Union's Splendid Coordination of Transport services', Illustrated London News, 12 October 1935.)
} 
distributed free of charge to employees of the SAR, recipients to the South Africa Railways Magazine and to patrons at the various SAR travel and tourist bureaux in South Africa and abroad. ${ }^{5}$ The text for the calendar of 1966 states explicitly: 'We acknowledge, frankly, that the calendar has been designed to stimulate the urge to travel ... [and] enjoy South Africa's scenic beauties.' The large numbers of these postcards with perforated edges found during the course of this research demonstrates that people did not discard them after the expiry of the calendar but did indeed keep them, as was intended.

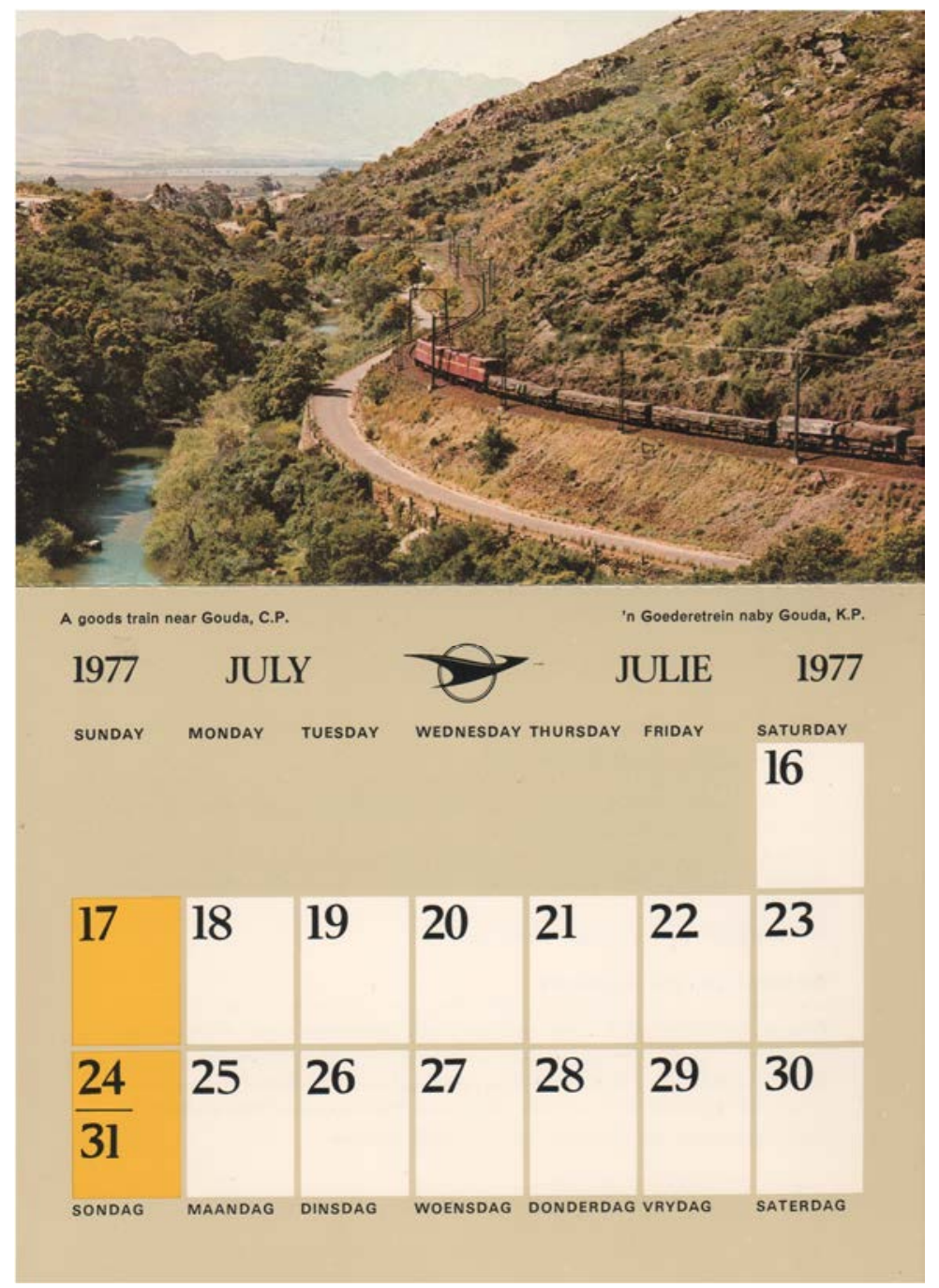

Fig 1. 'A goods train near Gouda, C.P.' SAR postcard, 1977. Courtesy of Transnet Heritage Library.

\footnotetext{
${ }^{5}$ Y. Meyer, Information Specialist, THL, personal communication, 10 October 2012. The travel bureaux were located in, in order of founding, Johannesburg, Cape Town, Durban, Pretoria, London, Lourenço Marques, East London, Port Elizabeth, Bulawayo, Kimberley, Bloemfontein, Windhoek, Pietermaritzburg, and George.
} 
The images on the SAR postcard calendars can be classified as topographical postcards, generally defined as comprising 'views of beaches, piers and promenades at seaside resorts or of mountains, lakes and forests ... tourist centres ... urban street scenes and general views. ${ }^{6}$ It is suggested here that the SAR postcards both formed and reflected popular middle-class ideas about the landscape and unspoilt nature, as well as the advances of modernity in the form of bustling cities, industries, bridges, dams, and above all trains. The ensuing dyad of nature/culture ties in with a far older colonialist discourse, and implicitly underlies the argument in this article. ${ }^{7}$ Postcards themselves are generally considered to be a significant index of modernity, echoing the modernity reflected in mass transportation and communication systems, rising literacy, tourism, and mechanical means of reproduction. ${ }^{8}$

The first postcards were produced in Austria in 1869 and they immediately became popular as a cheap, accessible and efficient form of communication. For almost twenty years they existed as plain correspondence cards, with no pictures. The picture postcard was born in 1889 with the Paris Exhibition and initially featured lithographic images, engravings and line drawings until improved and affordable technology made it possible to mass-produce photo-postcards around $1900 .{ }^{9}$ With the introduction of the so-called divided back format in 1902, the picture side (the

\footnotetext{
${ }^{6}$ C.W. Hill, Picture Postcards (Aylesbury, Shire, 1987), 7.

${ }^{7}$ Jeffrey Meikle investigates the utopian impulse in the Curt Teich postcards produced between the 1930s and 1950s in the USA and there are a number of similarities between these postcards and the SAR postcards discussed here, both of which seem to have mediated the land(scape) for a middle-class audience. J. Meikle, 'A Paper Atlantis. Postcards, Mass Art, and the American Scene', Journal of Design History, 13, 4 (2000), 267-286.

${ }^{8}$ N. Schor, 'Cartes Postales': Representing Paris 1900', Critical Inquiry, 18, 2 (1992), 209, 211.

${ }^{9}$ H. Woody, 'International Postcards. Their History, Production, and Distribution (circa 1895 to 1915)', in C.M. Geary and V.-L. Webb, eds, Delivering Views. Distant Cultures in Early Postcards (Washington. DC: Smithsonian Institution Press, 1998), 14-16.
} 
recto) became more important than the verso on which the message was written. ${ }^{10}$ The earliest postcards in South Africa, Transvaal Republican stationery cards with pictures on the verso, date from $1896 .^{11}$ Foster points out that from the early years of the twentieth century postcards were not only the foremost form of everyday communication, but were also the 'main source of cheap, readily-available images of South Africa. ${ }^{12}$ The photographic medium was easily able to "pass itself off as a replication of the "real"" and a reliable source of knowledge, without disclosing its latent ideological message. ${ }^{13}$ Consequently, postcards became one of the most important mediums through which people literally worked out how to visualize their world. ${ }^{14}$ Not only did postcards construct social ideas of nature, more importantly, in most cases they also created a 'network of nationally shared images.' 15

The research for this article derived from almost 400 topographical postcards published by the SAR between 1961 and 1984. Approximately a third of these were found in the Transnet Heritage Library in Johannesburg and the rest were collected between 2010 and 2012 in Pretoria, Johannesburg, and the Western Cape by means of so-called 'residual methodology,' which focuses on artefacts that have been discarded and end up at auctions, street markets, antique

\footnotetext{
${ }^{10}$ Schor, 'Cartes Postales', 212.

${ }^{11}$ A.K.W. Atkinson, 'South African Picture Postcards', Africana Notes and News, 25, 7 (1983), 227-228.

${ }^{12}$ J. Foster, 'Land of Contrasts or Home we Have Always Known'?: The SAR\&H and the Imaginary Geography of White South African Nationhood, 1910-1930', Journal of Southern African Studies, 29, 3 (2003), 671.

${ }^{13}$ P.C. Albers and W.R. James, 'Travel Photography. A Methodological Approach', Annals of Tourism Research, 15 (1988), 137.

${ }^{14}$ O. Löfgren, 'Wish You Were Here! Holiday Images and Picture Postcards', Ethnologia Scandinavica, 15 (1985), 91.

${ }^{15}$ G. Waitt and L. Head, 'Postcards and Frontier Mythologies: Sustaining Views of the Kimberley as Timeless', Environment and Planning D: Society and Space, 20 (2002), 320; S. Dotterrer and G. Cranz, 'The Picture Postcard: Its Development and Role in American Urbanization', Journal of American Culture, 5, 1 (1982), 49, emphasis added.
} 
shops and specialist collectors. ${ }^{16}$ Residual methodology implies that only a portion of the entire data set, whose size may not be known, can be used. Twenty-four postcards were produced for the postcard calendar each year and this means that for the period 1961 to 1984 , the total data set would comprise 552 postcards. The total of 378 postcards collected thus constitutes a $68 \%$ sample. As most of the postcards have been removed from the accompanying calendar section, it was only possible to date about two-thirds of them accurately, although contextual information was also useful. While the data set is not complete, even a relatively small sample can generate meaningful interpretations. ${ }^{17}$

This article starts with an overview of the SAR and its Publicity Department and the manner in which it structured an emerging South African tourist gaze. Thereafter, background is given regarding the postcards, calendars and postcard calendars produced by the SAR from about the 1920s onwards. The discussion then turns to the postcard calendars dating from 1961 to 1984 in terms of the three thematic clusters mentioned above. Postcards are never merely a neutral record of the world but are 'socially constructed and meaningful representations' that are invariably biased in terms of things like gender, class or race. ${ }^{18}$ Although the SAR, and by implication the South Africa government, was not the sole issuer of postcards as in some other countries, it

\footnotetext{
${ }^{16}$ S. Dubin, 'Symbolic Slavery: Black Representations in Popular Culture', Social Problems, 34, 2 (1987), 129. The Internet and specifically online auction sites such as EBay and Bid or Buy are also becoming useful archives for researchers. See D. Gifford, 'To You and Your Kin: Holiday Images from America’s Postcard Phenomenon, 1907 1910’, PhD, George Mason University, Fairfax, Virginia, 2011.

${ }^{17}$ A. Pritchard and N. Morgan, 'Mythic Geographies of Representation and Identity: Contemporary Postcards of Wales', Tourism and Cultural Change, 1, 2 (2003), 120.

${ }^{18}$ Albers and James, 'Travel Photography', 140; Schor, 'Cartes Postales', 216.
} 
nonetheless played a critical role in establishing ideological messages that deserves further investigation. ${ }^{19}$

\section{Contextualizing the SAR}

Although the first white settlement of South Africa was initiated by The Netherlands in 1652, Britain became the dominant imperial power after 1815, and kept this supremacy until the end of the South African War (1899-1902). The Union of South Africa was declared in 1910 and it became an independent dominion within the British Commonwealth during the 1920s, leading to a Republic in 1961. After Union, various white governments enforced segregationist policies that entrenched control of the land and economy. An initial solidarity between English and Afrikaans speaking South Africans during the early decades of the twentieth century was offset by the rise of language-based Afrikaner nationalism during the 1930s, culminating in the victory by the National Party in $1948^{20}$ and the inauguration of the apartheid era (until 1994).

The SAR must be understood against this backdrop of politics and economic development in South Africa. With the South Africa Act of 1909, the former discrete railway systems in the country were combined into the government-controlled South African Railway and Harbour Administration (SAR\&H) under the first General Manager, Sir William Hoy, and the Railways and Harbours Control and Management Act was promulgated in 1916. The SAR's control of all the harbours, train services, and motor bus services (Motor Carrier Transportation Act of 1930),

\footnotetext{
${ }^{19}$ See H.G. Lynn, 'Moving Pictures: Postcards of Colonial Korea', IIAS Newsletter, 44 (2007), 8 in terms of Japan. Sallo Epstein in Johannesburg was the largest postcard publisher in southern Africa at the turn of the nineteenth century. C.M. Geary, 'Different Visions? Postcards from Africa by European and African Photographers and Sponsors', in Geary and Webb, Delivering Views, 148.

${ }^{20}$ J. Foster, Washed with Sun. Landscape and the Making of White South Africa (Pittsburgh, Pa., University of Pittsburgh Press, 2008), 250.
} 
representing a virtual monopoly in terms of travel to and in South Africa, was completed by the incorporation of the South African Airways in 1934.

The SAR was for many years the largest single corporation in South Africa that not only totally transformed the economy, but also served as the primary employer for poor white workers, specifically during the impoverished $1920 \mathrm{~s}^{21}$ The SAR laid the foundations for overseas mail service, broadcasting, and film-making. As a 'government within a government' it was practically inseparable from government, and influenced almost every aspect of South Africa's social and economic life. ${ }^{22}$ In particular, the SAR was used strategically by the Union government to illustrate the material advantages of capitalism, imperialism, urbanisation and a modern, progressive unified nation. ${ }^{23}$ For many years the SAR dealt with the tensions between the imperatives of technological modernization/progress/civilization in relation to pre-modern landscape visions/untamed nature. ${ }^{24}$ In this regard, it is significant that the first generation of administrators of the SAR were Anglophile and worked in the colonial national interest of modernization. $^{25}$

The Afrikanerization of government that accompanied the triumph of the Nationalist Party in 1948 was also echoed by the Afrikanerization of corporations and key places such as the Kruger

\footnotetext{
${ }^{21}$ Foster, Washed with Sun, 202; J. Seekings, “"Not a Single White Person Should be Allowed to go Under”: Swartgevaar and the Origins of South Africa's Welfare State, 1924-1929', Journal of African History, 48 (2007), 383.

${ }^{22}$ Foster, 'Land of Contrasts', 661.

${ }^{23}$ Foster, 'Land of Contrasts', 661, 663; J. Foster, 'Northward, Upward: Stories of Train Travel, and the Journey Towards White South African Nationhood, 1895-1950', Journal of Historical Geography, 31 (2005), $304,310$.

${ }^{24}$ Foster, 'Northward, Upward', 304, 310.

${ }^{25}$ Foster, Washed with Sun, 203.
} 
National Park. ${ }^{26}$ Ideological shifts in the SAR were evident in its participation in celebrations linked to the inauguration of the Voortrekker Monument in 1949 and the Van Riebeeck Tercentenary in 1952. This saw the end the romanticization of South Africa as a place of personal aspiration and adventure that had characterized the politics of conciliation for the first 40 years of the twentieth century. ${ }^{27}$ The policies of segregation, both in terms of the SAR workforce and its commuters, led to huge financial losses from the 1970s onwards. In addition, the growth of individual car ownership, which exceeded a million by 1959 , led to a steep decline in the popularity of SAR rail travel and motor coach tours with white people. ${ }^{28}$

The SAR, as a 'quintessential symbol of modern nationhood and agent of territorial appropriation [and colonialism], the state-run railway ${ }^{29}$ needed an instrument by which to publicize its activities. Accordingly, in 1910, the 'advertising arrangements of the Administration were concentrated in a Publicity Branch at Headquarters. ... [Its most important task was] ordinary railway publicity work, such as the compilation and publication of newspaper, magazine and book advertisements, the preparation of guide-books, pamphlets and posters, and

\footnotetext{
${ }^{26}$ D. Bunn, 'An Unnatural State. Tourism, Water and Wildlife Photography in the Early Kruger National Park, in W. Beinart and J. McGregor, eds, Social History and African Environments (Cape Town, David Philip, 2003 ), 203. ${ }^{27}$ Foster, Washed with Sun, 40-42, 240-241, notes that attempts were made to gloss over the differences between whites and to establish a genealogy of South Africa as a white man's country in the early decades of the twentieth century.

${ }^{28}$ B.C. Floor, The History of National Roads in South Africa (Cape Town, CTP, 1985), 4. This growing lack of popularity of motor coach tours is reflected in the Annual Reports of the SAR in the 1970s. See also http://www.answers.com/topic/transnet\#ixzz2NiGhGpe0, accessed 16 March 2013.

${ }^{29}$ Foster, 'Northward, Upward', 306. The SAR opened up the interior of the country and made it less solitary, unspoiled and empty, but also fashioned 'a new subjectivity toward the landscape that was reflexive, collective, and national ... [creating a] shared white identification with the geographical place of the nation'. Foster, Washed with Sun, 201, 202.
} 
the distribution of photographs, etc. ${ }^{30}$ Under the astute headship of Mr A.H. Tatlow, ${ }^{31}$ the Publicity Department started to build up a collection of visual material, leading to the 'dissemination of photographic enlargements of South African scenery and industries in all parts of the world ... and the reproduction of photographs for the South African and oversea [sic] press. ${ }^{32}$ For many years, the annual reports of the SAR mentioned the importance of publicity in stimulating passenger traffic in order to develop holiday resorts but also to 'attract visitors and industrial investors to South Africa., ${ }^{33}$

The mainstay of the early publicity campaigns of the SAR was its stock of photographic material, which numbered 20,127 negatives by $1915 .^{34}$ These images were used in publications, posters and brochures, nationally and internationally, and were meant to inculcate and develop 'a

\footnotetext{
${ }^{30}$ THL, General Manager of Railways and Harbours Annual Report, 1910, 36.

${ }^{31}$ Tatlow started his career in South Africa in Natal, and became Manager of the South African Railways and Harbours Publicity Department in 1910. He was instrumental in publicizing the Union for 20 years, and was particularly involved with South Africa's exhibition at the Empire Exhibition in Wembley in 1924 and in founding publicity offices in London and New York (see note 32 below). 'Railway Publicity in South Africa - Publicity Manager's Retirement', The New Zealand Railways Magazine, 5, 3 (July, 1930), 1-9.

${ }^{32}$ THL, Annual Report, 1910, 37, emphasis added). Part of this initiative was also to "thoroughly "bioscope" South African scenery and industries' (THL, Annual Report, 1910, 37). African Film Productions was commissioned to produce documentary films that shaped the 'emerging notion of the new South Africa' and promoted tourism. E.
} Sandon, 'Preserving a Heritage? South African Archive Documentary: 1910-1940', Canadian Journal of Film Studies, 16, 1 (2007), 51, 54.

${ }^{33}$ THL, Annual Report, 1911, 43. This impetus was formalized at a conference organized by the Publicity Department of the SAR in November 1919 in Johannesburg at which over fifty South African delegates deliberated on ways of attracting tourists, farmers, settlers and manufacturers to South Africa. 'Making South Africa Known to Settlers and Tourists', S.A. Railways and Harbours Magazine, (January, 1920), 7. The Union's successful participation in the Empire Exhibitions in 1924 (Wembley), Johannesburg (1936), and Glasgow (1938) can be attributedto the role played by the SAR in the conceptualization of the national exhibits.

${ }^{34}$ THL, Annual Report, 1915, 109. 
spirit of interest and civic pride' in South Africans. ${ }^{35}$ Photographic enlargements of 'types of South African scenery' were accordingly used to make South Africa known to 'the right type of people. ${ }^{36}$ This was the first systematic visual recording of the country and many of the early views produced by the SAR became iconic, establishing a 'range of landscape motifs, effects, and points of view [that] ... acquired cultural currency' and shaped the way the landscape was seen and experienced by white South Africans ${ }^{37}$ for many decades.

It was repeatedly felt that an organization was needed to take care of the Union's overseas publicity. Consequently, Act no. 54 of 1947 promulgated the South African Tourist Corporation (Satour), and its office in London was opened in $1949 .{ }^{38}$ From the early 1950s onwards there was a clear demarcation between the mandate of the SAR Publicity Department and Satour - the former was meant to focus on domestic tourism and travel arrangements and the latter had to advertise South Africa as a holiday destination overseas. ${ }^{39}$ This distinction is important because it almost certainly had an effect on the target market of the postcard calendars referred to in this article. $^{40}$

\footnotetext{
${ }^{35}$ THL, Annual Report, 1925, 28.

${ }^{36}$ THL, Annual Report, 1925, 30-31.

${ }^{37}$ Foster, Washed with Sun, 212, 215. The SAR was the primary commissioner of images until after the Second World War. Foster, 'Land of Contrasts', 668.

${ }^{38}$ A Century of Transport (Johannesburg, Da Gama, 1960), 203.

${ }^{39}$ A Century of Transport, 202.

${ }^{40}$ This distinction is observable in the advertising material provided for overseas periodicals such as the Illustrated London News in the 1950s and 1960s. Satour advertised South Africa as a desirable holiday destination, whereas the SAR stated that it would help with organizing tickets, transport and accommodation (see Illustrated London News, 5 November and 19 November 1955 respectively for examples).
} 


\section{The first SAR postcards and pictorial calendars}

In order to trace the origins of the postcard calendars featured in this article, it is instructive to note that in 1929 the SAR's 'publicity propaganda material' comprised 'brochures, photographs, picture post cards, maps, press advertisements, posters, lantern slides and cinema films ${ }^{\text {,1 }}$ (fig 2). In 1933, it was noted that 13,094 pictorial postcards had been produced to attract holiday and business visitors to South Africa. ${ }^{42}$ Postcards were mentioned again in 1952, when it was recorded that 100 sets of postcards, consisting of 12 photographs of 'tourist attractions in South Africa' were to be distributed to 'prospective visitors to the Union.' 43

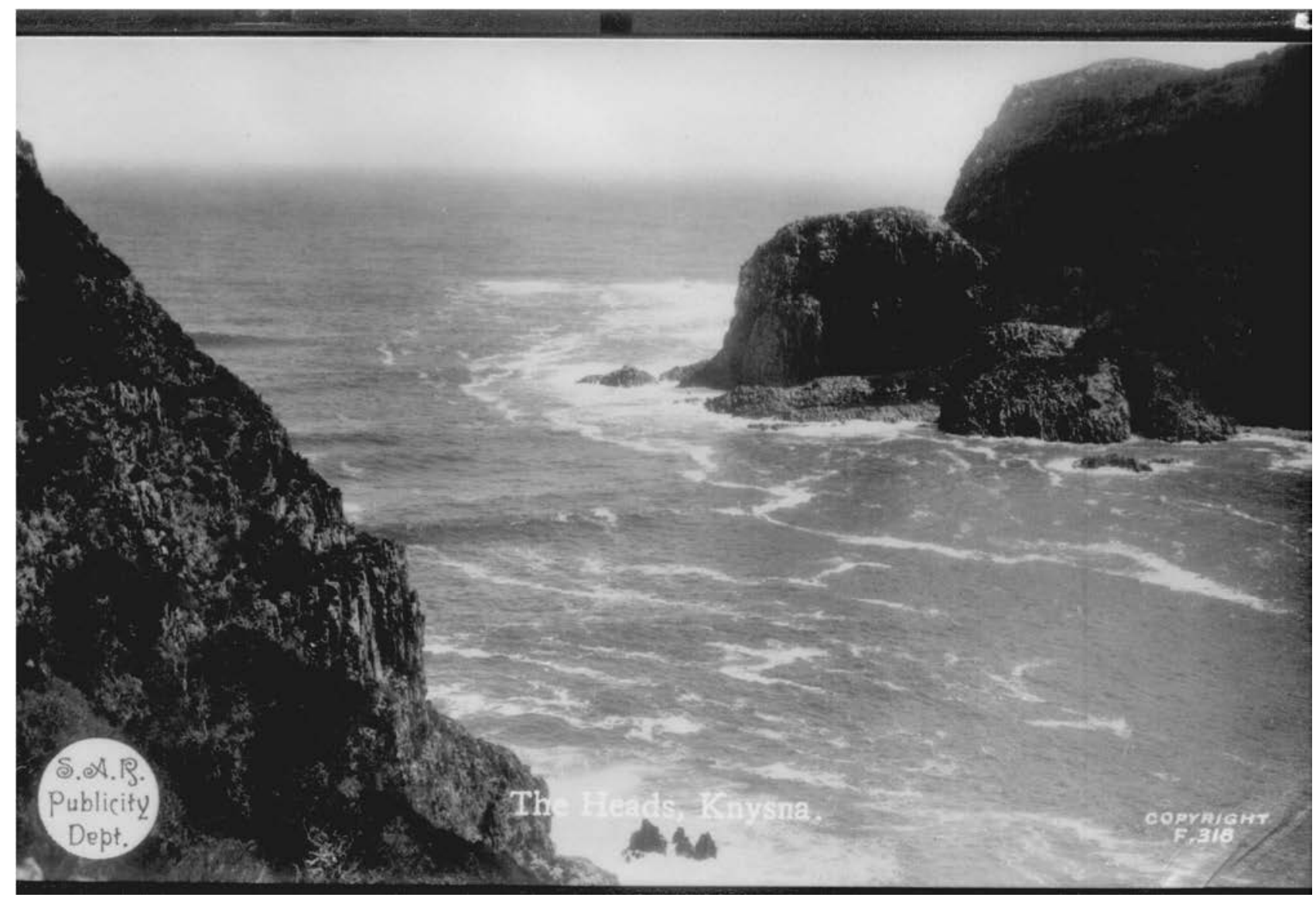

Fig 2. 'The Heads, Knysna.' Early black and white SAR postcard, ca. 1920s?. Courtesy of Transnet Heritage Library.

\footnotetext{
${ }^{41}$ THL, Annual Report, 1929, 36; emphasis added.

${ }^{42}$ THL, Annual Report, 1933, 61.

${ }^{43}$ THL, Departmental Reports, 1951-1952, 14.
} 
In 1934, a pictorial calendar in three colours, consisting of 'a selection of the well-known colourspreads published in overseas periodicals' was produced for the first time. ${ }^{44}$ In 1940, the Annual Report noted that the 'Department's pictorial calendar, of which 13,500 copies were printed, enjoyed considerable popularity overseas and was of great propaganda value. ${ }^{45}$ Shortages of paper during the Second World War hampered the production of publicity material, but by 1949 the pictorial calendar, which featured black and white photographs from the Department's stock, was again being produced and distributed in South Africa and overseas. ${ }^{46}$ By 1956, it incorporated 12 pictures in colour, which made 'an effective contribution to the publicity value of the production. ${ }^{47}$ In 1960, the centenary of the railways in South Africa, a prestigious 52page Centenary Calendar was produced that combined modern pictures with historical scenes. ${ }^{48}$ As previously mentioned, the new format of the postcard calendar discussed in this article appeared in 1961. The last mention of the postcard calendars is in $1982,{ }^{49}$ and the Publicity Department ceased to operate as a separate entity in about 1987.

The main purpose of the postcard calendar was to publicize the activities of the SAR and to stimulate interest in travel to South Africa: it was 'obvious that the annual circulation of these calendars provides a valuable medium for publicizing the South African Railways. ${ }^{50}$ In order to extend the impact of the calendars, the calendar pictures were sometimes reprinted and

\footnotetext{
${ }^{44}$ THL, Annual Report, 1934, 71.

${ }^{45}$ THL, Annual Report, 1940, 101.

${ }^{46}$ THL, Annual Report, 1949, 74.

${ }^{47}$ THL, Departmental Reports, 1955-1956, 8.

${ }^{48}$ THL, Departmental Reports, 1959-1960, 15. Because of its popularity, 30,000 Centenary Calendars were reprinted as a centenary album in 1961. THL, Departmental Reports, 1960-1961, 16.

${ }^{49}$ THL, Annual Report, 1981-1982, 35. It is possible that the increasingly negative economic climate in South Africa of the early 1980s and the poor performance of the SAR necessitated the curtailment of certain promotional activities. http://www.answers.com/topic/transnet\#ixzz2NiGhGpe0, accessed 16 March 2013.

${ }^{50}$ THL, Departmental Reports, 1950-1951, 9.
} 
distributed to, for instance, tourists 'on visiting cruise ships as mementos of their visit. ${ }^{51}$ The pictorial calendar was also distributed in the USA and to 'members of the British Railways Executive, travel agencies, shipping companies and numerous other concerns. ${ }^{52}$ In the years following the systematic institutionalization of apartheid and the effective ostracization of South Africa from the international arena, the postcard calendars continued to be distributed overseas but it seems as if the domestic market in Southern Africa became the main focus. The imperative to 'See your own country' or 'Know your own country' was frequently found in the SAR's publicity material, ${ }^{53}$ and resonated with the sentiment that tourism was actually a patriotic endeavour. $^{54}$

The design, production and distribution of the postcard calendars was done by the SAR Publicity Department. The Annual Reports consistently note their good reception: 'The S.A.R. Pictorial Calendar was well received, the general comment being that it was the most attractive production of its type which had been seen in the United Kingdom. The selection of photographs was admired by many people in the advertising world. ${ }^{55}$ The design and journalism section of the Publicity Department used photographs 'selected from stocks held by the photographic section',56 or took new ones in colour from 1956 onwards. The Annual Report remarked that 'while these added considerably to the cost, there is no doubt that they made an effective contribution to the publicity value of the production. ${ }^{57}$

\footnotetext{
${ }^{51}$ THL, Departmental Reports, 1957-1958, 8.

${ }^{52}$ THL, Departmental Reports, 1949-1950, 5.

${ }^{53}$ THL, Annual Report, 1949, 14.

${ }^{54}$ A.J. Gross, 'Cars, Postcards, and Patriotism: Tourism and National Politics in the United States, 1893-1929',

Pacific Coast Philology, 40, 1 (2005), 89.

${ }^{55}$ THL, Departmental Reports, 1948-1949, 10.

${ }^{56}$ THL, Annual Report, 1949, 74.

${ }^{57}$ THL, Departmental Reports, 1956-1957, 8.
} 


\section{The SAR and tourism}

The SAR played an inordinately influential role in South Africa in terms of not only providing the images that encouraged people to travel, but also the means to do so by virtue of its infrastructure and services. ${ }^{58}$ Tourism is one of the major domains in which photographic images are manipulated, usually in order to highlight historically constructed gazes and glances. ${ }^{59}$ As already mentioned, the SAR advertised its services through its extensive visual archive that came to constitute a 'network of nationally shared images.' As early as 1911, the SAR noted that apart from using advertising to attract visitors, settlers and industrial investors to South Africa, it 'stimulat[ed] passenger traffic and ... created an added interest in local resorts' such as Muizenberg. ${ }^{60}$ The SAR's early and astute identification of seaside resorts and other leisure destinations such as the Garden Route, the Kruger National Park and the Drakensberg established key holiday areas that continue to be popular. ${ }^{61}$

In 1926 there were only 6,356 tourists to South Africa, but this number grew annually by means of the shrewd publicity campaigns by the SAR that targeted the 'wealthy and travelling classes. ${ }^{62}$ Tourism increased after the Second World War as a result of international legislation regarding paid annual leave, more leisure time and disposable income, better transportation, and

\footnotetext{
${ }^{58}$ Foster, Washed with Sun, 234.

${ }^{59}$ Albers and James, 136; V. Bickford-Smith, 'Creating a City of the Tourist Imagination: The Case of Cape Town, “The Fairest Cape of them all", Urban Studies, 46, 9 (2009), 1765.

${ }^{60}$ THL, Annual Report, 1911, 43. The illustrated articles in the South African Railway Magazine, founded in 1905, also familiarized South Africans with the scenery of their country (e.g., articles on the Drakensberg, December 1919; Hermanus, April 1920; the Cape Peninsula, March 1925).

${ }^{61}$ C.M. Rogerson and Z. Lisa, “'Shot't Left': Changing Domestic Tourism in South Africa, Urban Forum, 16, 2-3 (2005), 93.

${ }^{62}$ THL, Annual Report, 1939, 108.THL, Annual Report, 1927, 31.
} 
sophisticated modes of visual marketing. ${ }^{63}$ As previously noted, under apartheid, domestic tourism was aimed at the needs of the privileged white minority who had disposable income, mobility, and access to all manner of tourism facilities. ${ }^{64}$ More than 100,000 visitors arrived in the $1950 \mathrm{~s},{ }^{65}$ although Grundlingh believes that tourism remained relatively low on the Nationalist government's agenda until the late 1950s when commercial jet aircraft and improvements to roads and infrastructure were effected. ${ }^{66}$ The Sharpeville killings in 1960 had a temporary negative effect on international tourism. The SAR reacted to the 'uncertain political conditions in Africa' and the 'falling off' of international visitors by turning more and more to the domestic market for support for its local tours. ${ }^{67}$ The buoyant economy in South Africa during the early 1960s was offset for the SAR by the realities of 'several factors which tend to limit the extent to which traffic, especially from overseas, can be increased', but the political situation was not explicitly mentioned as one of these. ${ }^{68}$ Foreign tourists to South Africa numbered over 400,000 by 1975 , but plummeted in the aftermath of the Soweto riots of June 1976 and continued to be lower into the 1980s. Despite this, publicity material produced during the 1960s and 1970s by Satour featured the usual images of sun, sea, sport and wildlife as,

\footnotetext{
${ }^{63}$ F. Ferrario, 'Emerging Leisure Market Among the South African Black Population, Tourism Management, 9,1 (1988), 28-29; D. Cosgrove, 'Introduction to Social Formation and Symbolic Landscape', in R.Z. DeLue and J. Elkins, eds, Landscape Theory (New York, Routledge, 2008), 31.

${ }^{64}$ Rogerson and Lisa, “'Shot't Left', 93.

${ }^{65}$ THL, Departmental Reports, 1959-1960, 1.

${ }^{66}$ A. Grundlingh, 'Revisiting the "Old” South Africa: Excursions into South Africa‘s Tourist History Under Apartheid, 1948-1990', South African Historical Journal, 56 (2006), 105-106.

${ }^{67}$ THL, Departmental Reports, 1960-1961, 2, 7.

${ }^{68}$ THL, Departmental Reports, 1963-1964, 2.
} 
according to Grundlingh, 'South Africa had to appear as an invitingly outdoor, exclusively white country, ${ }^{69}$ and the same tendency can be traced in the SAR postcard calendars discussed below.

\section{Discussion of postcards}

It should be noted that the postcard calendars discussed here are without exception very conservative in terms of their style and content. Both the form and content of the postcards seem to have remained virtually static in the period under discussion. Indeed, without occasional temporal signifiers, it would be almost impossible to distinguish between postcards from the 1960s and those from the 1980s as the visual rhetoric was unchanged. Part of the reason for this seems to be that the postcards served to capture the so-called timeless 'essence' of South Africa and represent it as a type of paradise that was untouched by the political or economic realities, especially of the 1970s and 1980s. Notwithstanding the real demographics of the country,South Africa was represented as an irredeemably 'white' country and a white, middle class audience was naturalized as the norm. Whereas the publicity material of the SAR in earlier years focussed mainly on familiarizing South Africans with 'their' country, one can speculate that by the second half of the twentieth century, and particularly as a result of apartheid politics, the emphasis shifted more to confirming white entitlement. Political and visual conservatism often collude in establishing the power of repressive regimes, and I believe this notion informs the SAR postcards, specifically in terms of the inherently persuasive naturalism of the photographic medium referred to above. It should also be remembered that images generated at that time would have had to appeal to a generation that was still generally unsophisticated in terms of visual culture and that had to be reassured of the stability of their world.

\footnotetext{
${ }^{69}$ Grundlingh, 'Revisiting', 110. The Annual Reports of the SAR from the late 1960s onwards devoted far less attention to the activities of the Publicity and Travel Department and totally failed to engage with or refer to the political turmoil of the 1970s and 1980s.
} 
In dividing the postcards into thematic clusters, I attempted to do so in the spirit of the times and the purpose for which in which they were created, which means, for example, that it would have been entirely acceptable to relegate black people to 'the world of nature' as this was the primary mode in which they were generally represented.

The following themes were accordingly identified in the images on the postcard calendars: landand seascapes; flora and fauna; indigenous cultures; monuments, heritage and public buildings; leisure and tourism spaces and activities; cities, roads, industry and dams; and SAR-related topics (e.g., trains, harbours, motor coaches, and airplanes) (Table 1). These themes were then arranged in three broad clusters: the natural world; the world of culture; and related to this, the world of technology, modernity and progress. ${ }^{70}$ A stratified sample was drawn from the subgroups in the clusters. Yet again, the sample seemed to be representative enough to attempt to answer the question of how the SAR represented the country through the medium of postcards and to be able to understand how issues of power might have informed this representation. In other words, the sample is sufficient in order to determine which images and identities are foregrounded and which are silenced, omitted or marginalized. ${ }^{71}$

\footnotetext{
${ }^{70}$ C.K. Corkery and A.J. Bailey, 'Lobster is Big in Boston: Postcards, Place, Commodification, and Tourism', GeoJournal, 34, 4 (1994), 491-498 identify similar attributes: heritage; shopping; academe; tourism; night scenes; and the metanarratives of science and technology.

${ }^{71}$ Pritchard and Morgan, 'Mythic Geographies', 121.
} 
Table 1: thematic clusters in the SAR postcards (Compiled by author).

\begin{tabular}{|l|l|}
\hline The world of 'nature' & 30 \\
\hline Wildlife, birds, flowers & 10 \\
\hline Black people & 69 \\
\hline Land- and seascapes & \\
\hline (15 with humans) & 109 \\
\hline & \\
\hline The world of 'culture' & 45 \\
\hline Leisure activities & 15 \\
\hline Tourism resorts, game parks, hotels, parks & 378 \\
\hline Monuments, public buildings & 28 \\
\hline transport, lighthouses & 38 \\
\hline The world of 'technology and progress' & \\
\hline Cities, industries, dams & 37 \\
\hline SAR: station buildings, people on trains & \\
\hline
\end{tabular}

Following the pioneering work of Albers and James, the majority of postcard studies combine quantitative with qualitative analysis. ${ }^{72}$ Quantitative content analysis is useful for establishing the frequency of certain visual elements (e.g. images of technology) and works best when the categories for coding are already interpretive. ${ }^{73}$ Semiotic analysis can then be used to reveal how recurring codes operate to encode ideological meanings (e.g. who or what is absent or erased from representation) and deals with latent, symbolic and metaphorical intentions. ${ }^{74}$ Content

\footnotetext{
${ }^{72}$ See Corkery and Bailey, 'Lobster is Big'; Dubin, 'Symbolic Slavery'; M. Markwick, 'Postcards from Malta. Image, Consumption, Context', Annals of Tourism Research, 28, 2 (2001); Pritchard and Morgan, 'Mythic Geographies'.

${ }^{73}$ G. Rose, Visual Methodologies. An Introduction to Researching with Visual Materials, (London, Sage, 2012), 87, 91.

${ }^{74}$ Albers and James, 'Travel Photography', 145-149; P. Raento, 'Tourism, Nation, and the Postage Stamp.Examples from Finland', Annals of Tourism Research, 36, 1 (2009), 129.
} 
analysis does not generally reveal much about the production or audience of visual images, and is most useful when it is combined with intertextual cross-checks to enhance reliability. ${ }^{75}$ Some scholars hold that the production, collection and reception of postcards is just as important as the interpretation of their visual imagery as these interrogate notions of authority, originality, class, gender, and power. ${ }^{76}$ The postcards discussed in this article were all produced and disseminated by the SAR. Although patterns of consumption have not been established, it is indicative that so many postcards have survived, suggesting that they were not necessarily considered to be transient. More research is needed in order to ascertain more clearly how these postcards 'worked' as opposed to what they 'meant', ${ }^{77}$ but they are read here contextually as products of culture that encapsulated and reflected an ideological imperative.

\section{The world of 'nature'}

Like many other countries that bear a colonial legacy, South Africa has consistently been represented by stereotypes that align it irredeemably with the natural, unspoilt world of wildlife and 'primitive tribalism'. ${ }^{78}$ This romance of the land and exotic otherness is again and again offset by the rhetoric of development, modernity, civilization, and industrialization (see below). Consequently, the 'predominant set of codes through which South Africa has been represented and imaged is through variants of a dichotomy between the conditions of "modernity" and

\footnotetext{
${ }^{75}$ Rose, Visual Methodologies, 86; S. Jokela and P. Raento, 'Collecting Visual Materials from Secondary Sources', in T. Rakić and D. Chambers, eds, An Introduction to Visual Research Methods in Tourism (London, Routledge, 2012), 67.

${ }^{76}$ D. Prochaska and J. Mendelson, 'Introduction', in D. Prochaska and J. Mendelson, eds, Postcards. Ephemeral Histories of Modernity (University Park, PA., Pennsylvania State University Press, 2010), xi-xii.

${ }^{77}$ D. Prochaska, 'Thinking Postcards', Visual Resources, 17 (2001), 383.

${ }^{78}$ C. Rassool and L. Witz. 'South Africa: A World in One Country. Moments in International Tourist Encounters with Wildlife, the Primitive and the Modern', Cahiers d'Études Africaines, 143, 36 (1996), 336.
} 
"primitiveness.", ${ }^{79}$ For the colonialist and tourist, 'Africa' was the quintessence of untamed and unspoilt nature and 'pristine peoples;' accordingly, African culture and history have usually been considered less compelling than its wildlife ${ }^{80}$ (fig 3). Lowenthal points out that in 'new' places such as America and Australia, the natural past is usually accorded more prominence that the cultural past, helping to locate 'roots in nature. ${ }^{81}$ This colonial tradition of essentializing Africa as the site of exotic animals negated human presence ${ }^{82}$ or reduced it to tribal clichés, as well as establishing nature as the site for nostalgia. Grundlingh asserts that during the 1960s, South Africa as a tourist destination was still principally associated with outdoorism, primitivism, wildlife and leisure. ${ }^{83}$

\footnotetext{
${ }^{79}$ Rassool and Witz.'South Africa', 364. This discourse was already apparent at the Wembley Empire Exhibition in 1924 and the Empire Exhibition in Johannesburg in 1936. J. Woodham, 'Images of Africa and Design at the British Empire Exhibitions Between the Wars', Journal of Design History, 2, 1 (1989); C. Coe, 'Histories of Empire, Nation, and City: Four Interpretations of the Empire Exhibition, Johannesburg, 1936', Folklore Forum, 32, 1/2 (2001).

${ }^{80}$ W. Van Beek. 'Approaching African Tourism: Paradigms and Paradoxes', in P. Chabal, U. Engel and L. De Haan, eds, African Alternatives (Leiden, Brill, 2007), 154, 162-163.

${ }^{81}$ D. Lowenthal, The Past is a Foreign Country (Cambridge: Cambridge University Press, 1985), 53-54.

${ }^{82}$ J. NedervenPieterse, White on Black: Images of Africa and Blacks in Western Popular Culture (New Haven, Yale University Press, 1992), 35.

${ }^{83}$ Grundlingh, 'Revisiting', 110-111.
} 


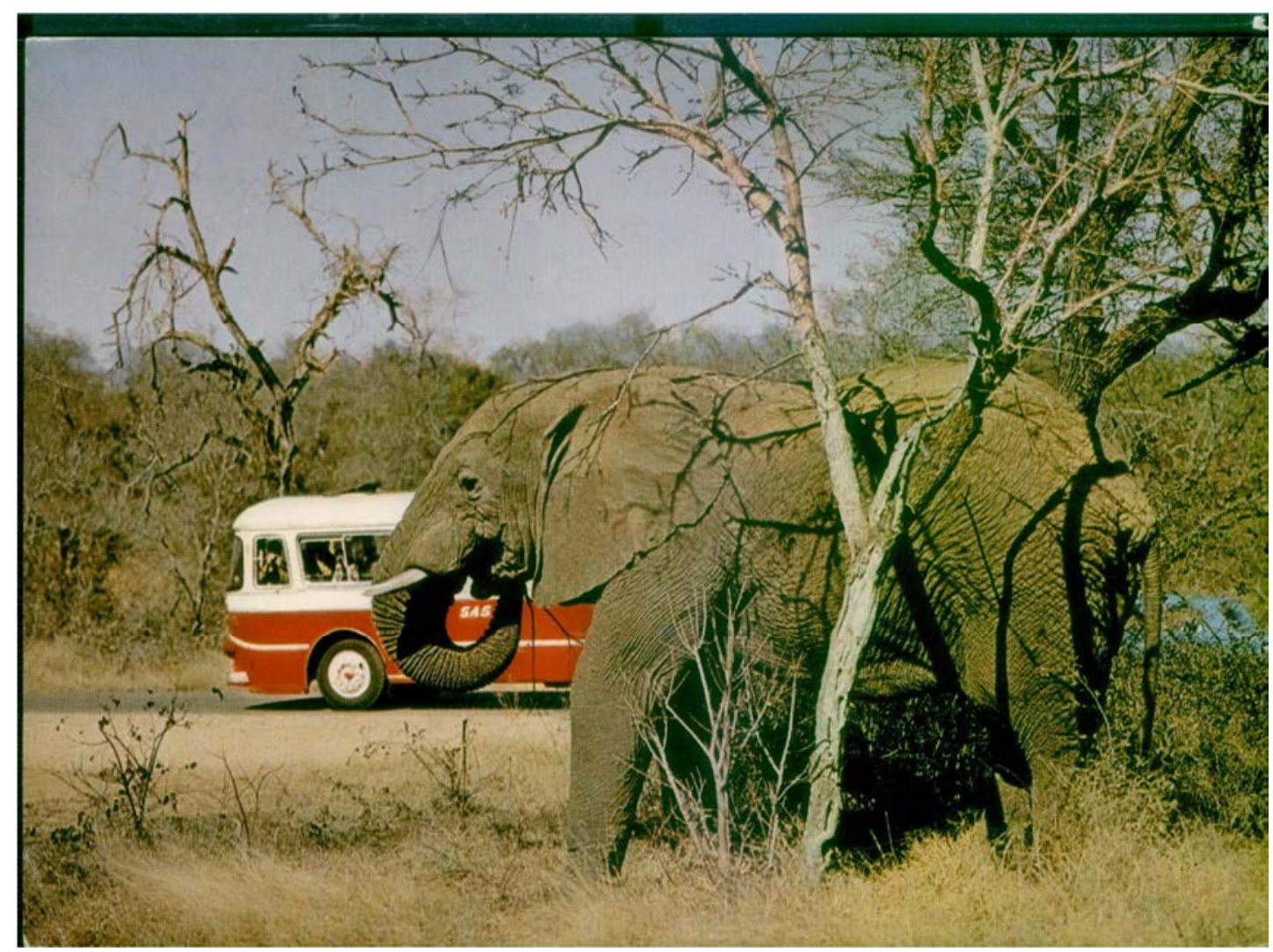

Fig 3. 'S.A. Railway motor coach in the Kruger National Park.' SAR postcard, 1974. Courtesy of Transnet Heritage Library.

The extant SAR postcards of animals (30) depict only two sites: the Kruger National Park (KNP) and the Etosha National Park, South West Africa (now Namibia, but part of South Africa until 1990). In other words, this vision of wildlife in its 'natural' state is already a mediated construct. Proclaimed in 1926, the KNP became the focus point of an imaginary geography based on pristine, untouched nature under the custodianship of white man that was used to bolster ideas of national identity and unity between white people in South Africa. ${ }^{84}$ The SAR organized package tours to the KNP in the 1920s; as roads and hotels were still in their infancy, the tourists slept on the trains. ${ }^{85}$ The SAR thus played a strategic role in the construction of the KNP as a tourist

\footnotetext{
${ }^{84}$ See J. Carruthers, 'Dissecting the Myth: Paul Kruger and the Kruger National Park, Journal of Southern African Studies, 20, 2 (1994), 263-283. Foster, Washed with Sun, 69-71, suggests that the identification of white South Africans with wild animals was expedited by their 'erasure of indigenous human inhabitants in favour of indigenous fauna.'

${ }^{85}$ Foster, Washed with Sun, 200-201.
} 
destination, and this is reiterated in figure 3 that shows a SAR motor coach there in 1974 . The size and majesty of the elephant signify the world of nature, and although it is benign, it nonetheless dwarfs the tourist bus. The visitors represent the domain of modernity and culture. This is embodied by the two tourists taking photographs from inside the bus, which also underscores the spectacularization of Africa.

It was stated above that black people are represented in the SAR postcards in the domain of nature. This alludes to the fact that so-called tribal people are generally depicted literally 'rooted in the soil, subsumed in nature, an extension of another natural world' to suggest their supposed closer association with nature. ${ }^{86}$ Meikle confirms that 'native' people are invariably objectified as "part of the landscape ... exotically fascinating and wholly "other"'; their faces are averted and they are only seen from a distance. ${ }^{87}$ This concurs with the ten SAR postcards that depict black people. Four postcards show fishermen at the Cape, one shows labourers in a vineyard, another show workers in a pinery (fig 4) and one shows herders with their cattle. One postcard depicts an Indian spice seller in Durban and another shows a 'typical' Ndebele woman in front of her homestead with its characteristic mural decoration. One postcard shows two immobile figures in the Zululand landscape (captioned 'Zululand'), and the last depicts an ostrich race, which was often enacted for tourists in the Oudtshoorn district.

The colonialist trope of 'industrious blacks' overseen by benevolent and paternalistic white people (fig 4) was typical of the manner in which the SAR represented black people as either ‘anthropological curiosities' or as 'noble savages', neither of whom could challenge white

\footnotetext{
${ }^{86}$ Markwick, 'Postcards from Malta', 428.

${ }^{87}$ Meikle, 'A Paper Atlantis', 274.
} 
hegemony. ${ }^{88}$ Despite the fact that they are engaged in productive tasks, they are positioned as technologically backward, anonymous 'types' closer to nature than to culture. This is underscored by the caption of the postcard: 'The golden harvest.' The black women, one of whom is bare-breasted, ${ }^{89}$ are intermediaries for the bounty of nature they carry on their heads. The domain of white hegemony is suggested by the white (presumably) farmer and his wife. They stand separate from the labourers in the fields and they present a pineapple to a white female visitor, adorned with a token 'native' grass hat. The wealth of the farmer is suggested by the extent of the pineries and it is probable that it is his imposing house that is situated on the far horizon. $^{90}$

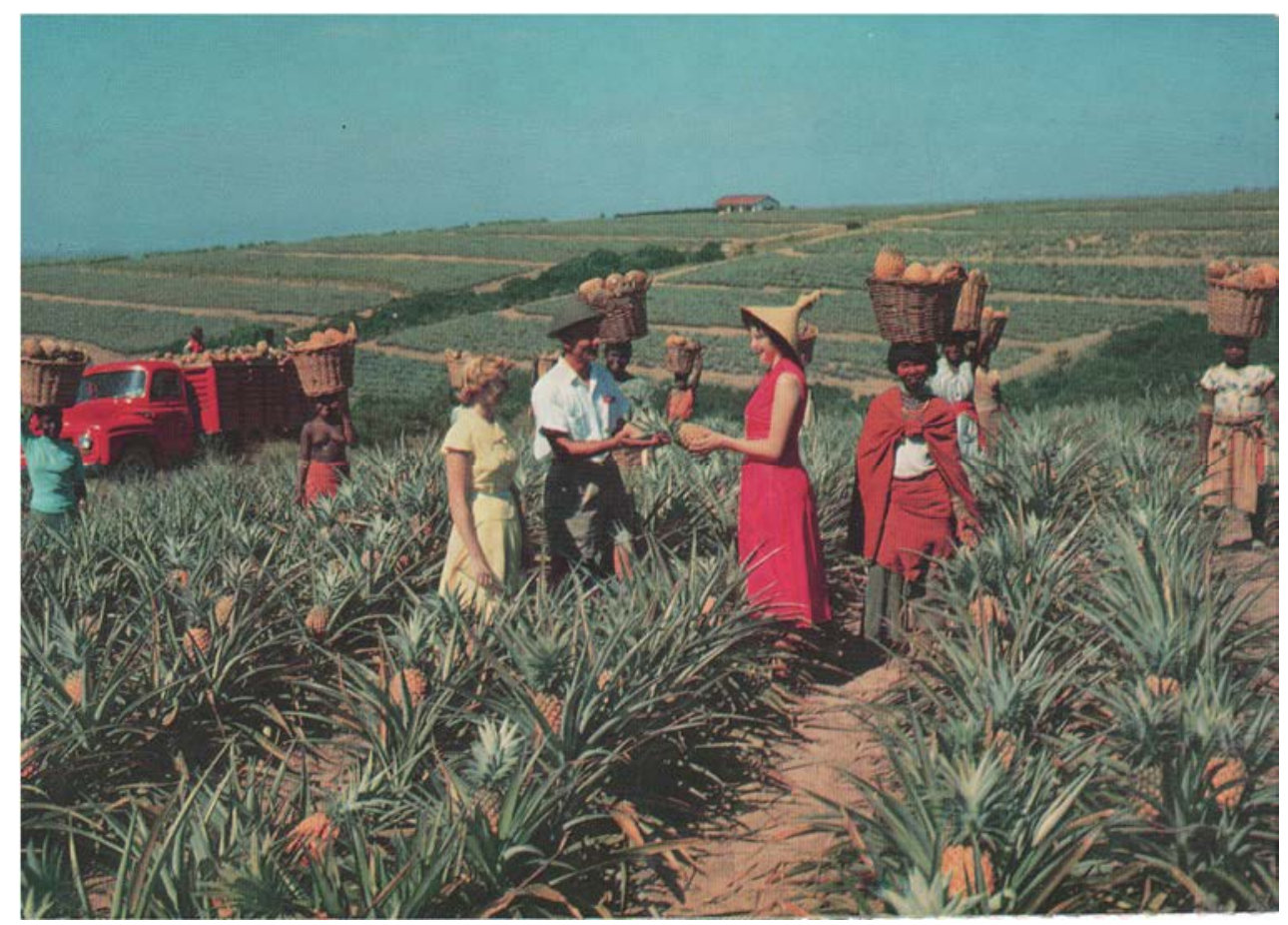

Fig 4. 'The golden harvest. Pineries near East London.' SAR postcard, ca. early 1960s. Courtesy of Transnet Heritage Library.

\footnotetext{
${ }^{88}$ Foster, Washed with Sun, 227-228, 256. See also 'Native Types and Life', S.A. Railways and Harbours Magazine, December 1920, 1021-1025.

${ }^{89}$ The partial nudity of the black woman again served to establish her otherness and 'primitive' state at a time when images of nudity of white women were subject to strict state censorship.

${ }^{90}$ The trope that featured the romance of the productive land was very common in SAR 'publicity propaganda' during the 1920s that sought to attract Europeans to settle in South Africa. 'Making South Africa Known', S.A.
} Railways and Harbours Magazine (January, 1920), 7. 
The last group of postcards that deal with nature portray the landscape. The notion of landscape as a vehicle of ideological statements regarding ownership, inclusion, and entitlement is important and is validated by the large number of postcards in this category (69). The politics of colonialist and capitalist expansionism was extended by the capacity of powerful institutions, such as the SAR, to impose its view on landscape or to manipulate images of it. ${ }^{91}$ Foster structures a compelling argument concerning South African nation building as instrumentalized by the SAR's visual archive and shows how the lure of wide open spaces came to be associated with South Africanism throughout the first half of the twentieth century. ${ }^{92}$ The manner in "which all whites came to identify with and "place" themselves in the imagined nation of South Africa' was intimately related to the way in which the visual representation of the shared territory was entrenched in visual and textual reiterations. ${ }^{93}$ The Publicity Department of the SAR played a crucial role in this, not only by documenting the country visually, but also by creating iconic views that formed a conceptual prism through which notions of nationhood and the idea of South Africa as a 'white man's country' were read. ${ }^{94}$ The landscape views of the Cape Peninsula and the Drakensberg, for example, established landscape preferences that contributed to the narrative of white South African identity (and 'network of nationally shared images') deep into the second half of the twentieth century. ${ }^{95}$

\footnotetext{
${ }^{91}$ S. Zukin, Landscapes of Power: From Detroit to Disney World (Berkeley, University of California Press, 1991), 16.

${ }^{92}$ Foster, Washed with Sun, 73-74.

${ }^{93}$ Foster, Washed with Sun, 46-47, 64.

${ }^{94}$ Foster, Washed with Sun, 40-42, 49, 86-87.

${ }^{95}$ Bickford-Smith, 'Creating a City', 1770; J. Pickles, 'Images of Landscape in South Africa with Particular Reference to Landscape Appreciation and Preferences in the Natal Drakensberg' (PhD, University of Natal, Pietermaritzburg, 1978).
} 
The identification with the (white man's) land had to be supported by the physical exploration and embodied experience of it; 'the land itself came to be seen as a significant determinant of ... South African society. ${ }^{96}$ Thus it was that the invitingly empty landscape became the stock in trade of SAR imagery as it allowed an imaginary and idealized geography of the national whole, 'grounded in the scenic', to take root. ${ }^{97}$ Crais observes that the myth of the empty or vacant land betokened both geographical emptiness or unused land in addition to the literal empty land in which indigenous people are rendered invisible. ${ }^{98}$ Typical of this trope was the expansive panoramic view, usually from a promontory, of the immensity of the countryside wherein the people gazing at the land 'could feel comfortable in their possession of it." 99 This trope continued to be important throughout the period discussed in this article and features in a significant number of postcards, suggesting the need to confirm white presence visually in the land during a period of growing political unrest.

The women who confidently take in the vastness of the Blyde River Canyon in the Eastern Transvaal (fig 5) assert and legitimate the right to white presence and ownership. They are characteristic of the modern tourist who consumes landscape aesthetically as a leisure activity; they take in the land laid out like a panorama for their evaluative gaze. Their possession is performed by means of vision and technology - the woman on the left wields the arch-weapon of

\footnotetext{
${ }^{96}$ Foster, 'Northward, Upward', 302-303.

${ }^{97}$ Gross, 'Cars, Postcards', 79.

${ }^{98}$ C.C. Crais, 'The Vacant Land: The Mythology of British Expansion in the Eastern Cape, South Africa', Journal
} of Social History, 25, 2 (1991), 257. This resonates not only with the rhetorical strategies of colonial discourse but also with the landscape vision of contemporary South African painters such as Jacob Hendrik Pierneef (1886-1957). Pierneef's 30 large landscape panels commissioned by the SAR for Park Station in Johannesburg, completed in 1930, totally erase black people from the South African landscape.

\footnotetext{
${ }^{99}$ Meikle, 'A Paper Atlantis', 273. Views from the top of Table Mountain in Cape Town were especially iconic and can be found in numerous postcards from the early years of the twentieth century even before the SAR started its visual archive.
} 
the tourist, the camera. This comparison is not gratuitous - Susan Sontag notoriously described the camera as a 'predatory weapon' and pointed out that photography developed simultaneously with modern tourism. ${ }^{100}$ Unsurprisingly, there are no comparable SAR postcards wherein black people enact their right to the land in a similar way; all the landscape postcards in this sample convey the same one-sided view of the land. ${ }^{101}$

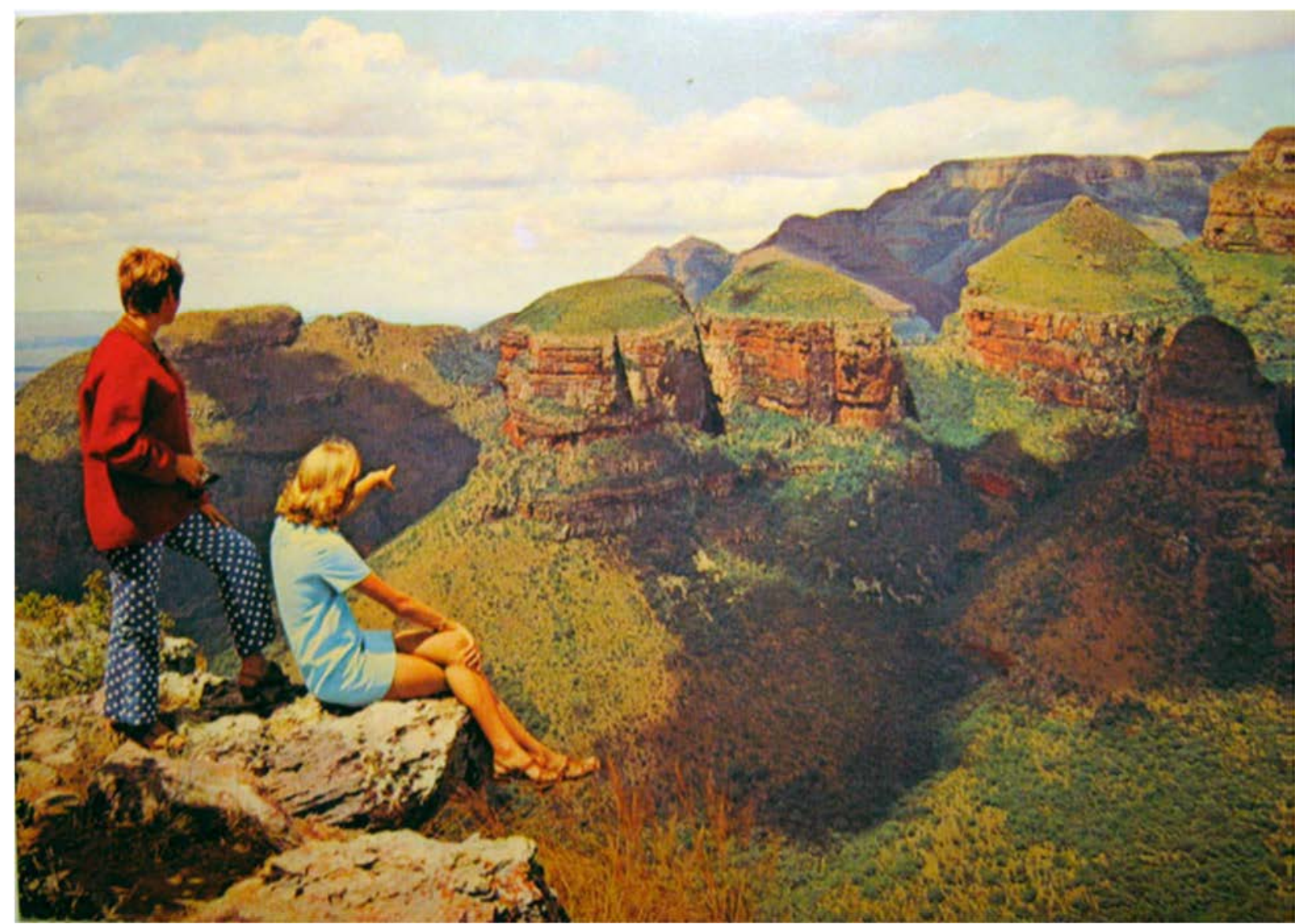

Fig 5. 'The Blyde River Canyon near Pilgrim's Rest, E. Tvl.' SAR postcard, ca. early 1960s. Courtesy of Transnet Heritage Library.

\footnotetext{
${ }^{100}$ S. Sontag, On Photography (New York, Picador, 1973), 9, 14. This association is underscored by a travel advertisement by the SAR in 1957: 'En onthou: 'n reisiger sonder 'n kamera is soos 'n jagter sonder sy geweer. BRING U KAMERA SAAM! ('Remember, a traveller without a camera is like a hunter without his gun. BRING YOUR CAMERA! My translation). Lantern, October (1957), 6.

${ }^{101}$ For more on the manner in which landscapes were represented in SAR postcards, see J. Van Eeden, 'Surveying the 'Empty Land' in Selected South African Landscape Postcards', International Journal of Tourism Research 13, 6 (2011, 600-612.
} 


\section{The world of 'culture'}

The world of 'culture' as represented in the SAR postcards is related to notions of class, constructed national identity, conspicuous leisure and 'leisure imperialism'. ${ }^{102}$ South Africa is yet again depicted as an exclusively white country; as Grundlingh remarks in the context of Satour marketing, 'black people did not make a guest appearance, not did they even appear as a kind of animated geographical background. ${ }^{103}$ The reality of black labour that made possible the leisured entitlement of the minority of the population is totally elided. The leisure activities in which white people participate in the postcards include fishing, pony trekking, horse racing, bowls, golf, yachting, and of course swimming and lying on the beach. The people depicted at the beach are invariably young and attractive (fig 6) and embody the stereotypical connotations of sun, sex, sea, and sand. The two female figures in figure 6 are dressed in scant bikinis and pose at the exclusive Clifton Beach. Its sought-after bungalows and flats form the backdrop and establish a clear class position for the beach on which only white people enjoy themselves.

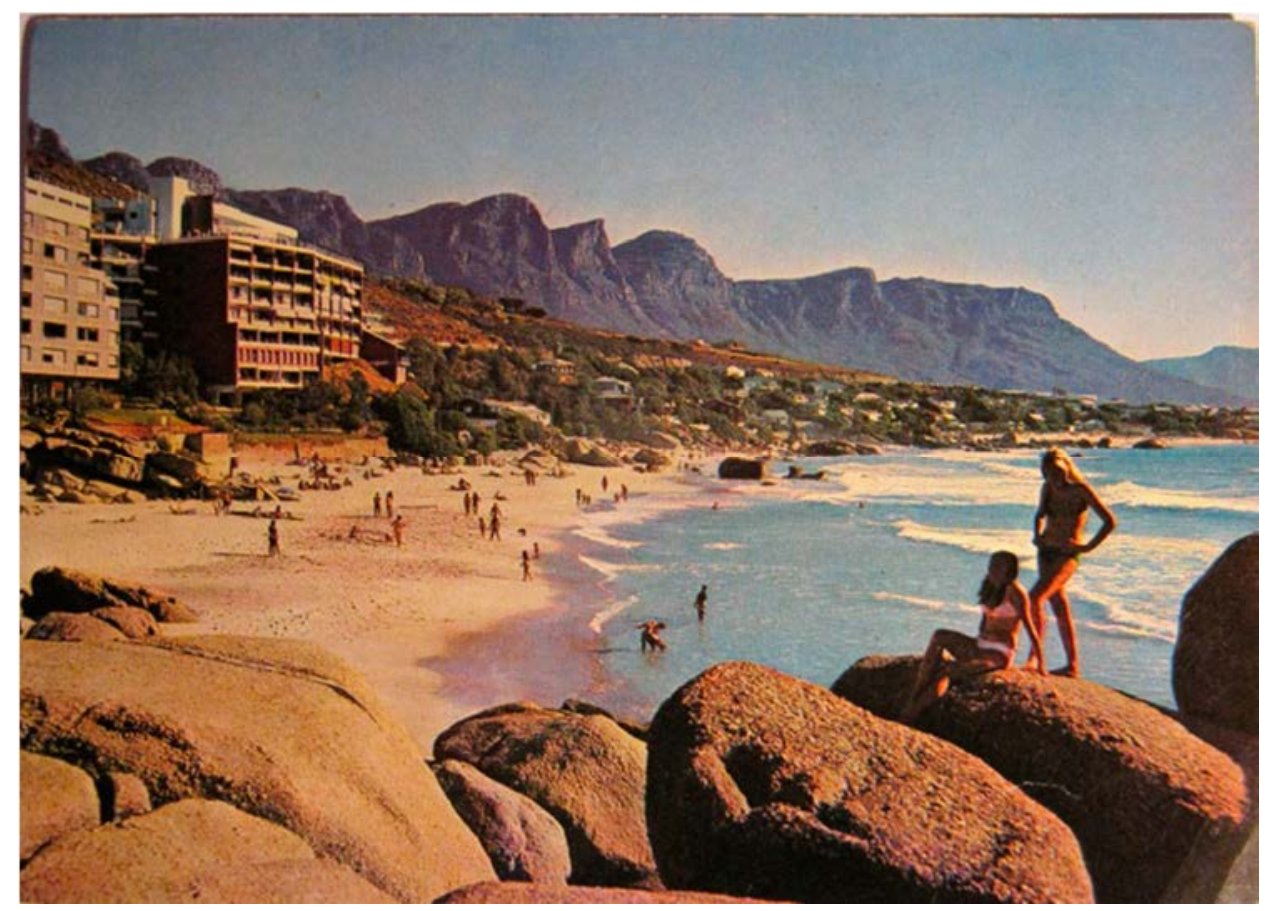

Fig 6. 'Clifton Beach, Cape Town.' SAR postcard, 1971. Courtesy of Transnet Heritage Library.

\footnotetext{
${ }^{102}$ M. Crick, 'Representations of International Tourism in the Social Sciences: Sun, Sex, Sights, Savings, and Servility', Annual Review of Anthropology, 18 (1989), 322.

${ }^{103}$ Grundlingh, 'Revisiting', 110.
} 
The people who participate in the other activities are commonly depicted as older or more sedate, such as those playing bowls at a resort in the Drakensberg (fig 7). All the figures are contained within the confines of the neatly clipped lawn and the surrounding hedge, which establish a border with untamed nature in the background. It is perhaps significant that the activity they participate in has no resonance with the majestic mountain backdrop; that is, they are not shown climbing the mountain or enjoying the view. Most of the people who are depicted in postcards showing tourism resorts or sites, game parks, hotels and parks fall into this age (and class) category.

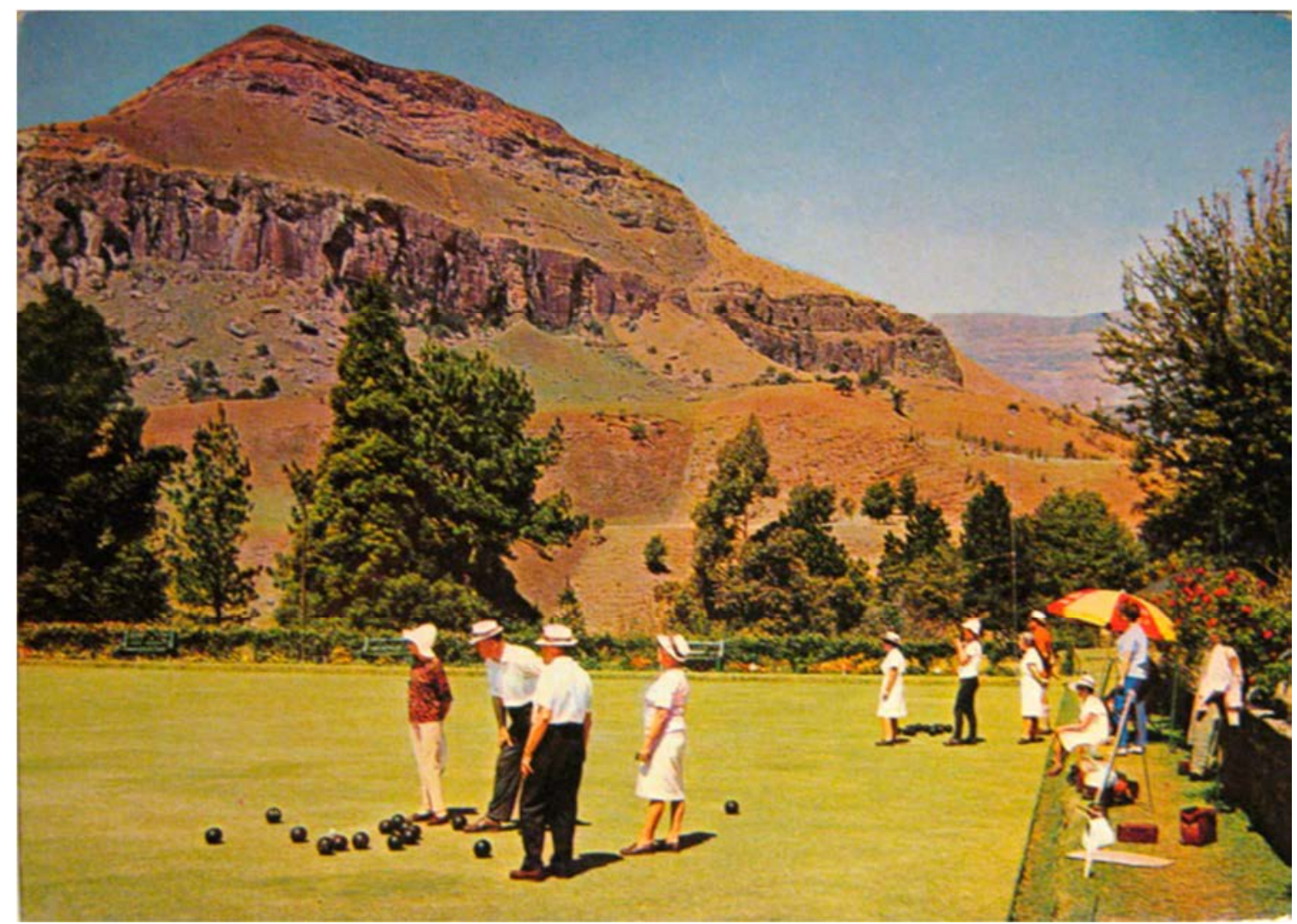

Fig 7. 'Cathedral Peak, Drakensberg, Natal.' SAR postcard, 1971. Courtesy of Transnet Heritage Library.

The postcards that depict monuments and public buildings offer an exclusive view of white, primarily Afrikaner, settlement, heritage and culture: the Union Buildings in Pretoria, the Huguenot Memorial in Franschhoek, statues of Afrikaner heroes like Paul Kruger, J.B.M. Hertzog and J.G. Strijdom, the Pretoria City Hall, the Public Library in Johannesburg, Groote Schuur Hospital in Cape Town, the University of South Africa in Pretoria, various (mainly neo- 
Gothic) church buildings, and iconic Cape Dutch houses such as Groote Schuur in Cape Town. Only one postcard depicts a 'Bantu church, De Beers Diamond Mine, Kimberley', and even this can be read as an expression of the penetration of white capital rather than being a testament to black culture.

The world of 'culture' represented in these postcards is constructed on a network of signifiers that operated within the circuit of culture to convey specific class and race positions. Firstly, as mentioned previously, the SAR expedited the development of many holiday resorts by its network of trains and motor coaches that linked these spaces of pleasure to the metropole. ${ }^{104}$ The idea of middle-class travel purely for leisure purposes was a new phenomenon that was made possible by the railways. Secondly, this urbanized middle class could afford to travel and had the leisure time to do so. Thirdly, the habit of retreating to nature for leisure was also related to a class position. ${ }^{105}$ Pickles has pointed out that a preference for the Drakensberg in the 1970s was aligned with a specific socio-economic profile consisting of well-educated, English-speaking, high income professional urbanites, usually married but with few children (fig 7). ${ }^{106}$ Contrary to this, the Natal South Coast appealed to younger, single, lower income English and Afrikaans speaking holidaymakers who had less formal education and were employed in production or

\footnotetext{
${ }^{104}$ Fashionable seaside resorts such as Sea Point and Muizenberg were linked by rail to Cape Town in order to facilitate the spending of leisure time. Foster, Washed with Sun, 210-211. Some of the earliest roads in South Africa were also built with the idea of leisure in mind. As early as 1908, the Cape Peninsula Publicity Association and the Cape Automobile Club lobbied for better roads to enable tourism around the Cape Peninsula. Work started on the All Round the Cape Peninsula Road in 1913 and it was completed in 1923. R.H. Johnston and D. Stuart-Findlay, The Motorist's Paradise. An Illustrated History of Early Motoring in and around Cape Town (Cape Town, Tandym, 2005), 50-52.

${ }^{105}$ Raento, 'Tourism, Nation', 137, 142; Löfgren, 'Wish You Were Here', 92.

${ }^{106}$ Pickles, 'Images of Landscape', 340-341.
} 
clerical work. ${ }^{107}$ These patterns of consumption had been established from the beginning of the twentieth century when Durban, for example, was developed as a coastal resort by the Durban Corporation specifically to draw people from the industrial interior of South Africa. ${ }^{108}$ The scene in figure 6 of upmarket Clifton is therefore not typical of the SAR postcards, most of which do indeed concentrate on popular beaches in places such as Durban.

Fourthly, these landscape preferences were underscored by the production of postcards for the domestic market that reflect this 'shared or similarly grounded consumption of culture. ${ }^{109}$ From the early twentieth century onwards, real photo postcards were embraced by upwardly mobile consumers and became markers of cultural capital. ${ }^{110}$ Lastly, the process of forging national identities is related to the construction of shared narratives and memories; so, for example, the Cape Dutch architectural style was elevated from the early decades of the twentieth century to an iconic 'national style' based on a putatively shared white heritage. ${ }^{111}$ Heritage sights could accordingly project 'a hegemonic official discourse of nationalism', and gables 'became emblematic of an idealised and romanticised history. ${ }^{112}$ The Cape Dutch style that featured at the inter-war year Empire Exhibitions and on SAR posters with other popular images such as 'Bushman' paintings and the Drakensberg ${ }^{113}$ thus created a social imaginary of white South Africa, as previously suggested.

\footnotetext{
${ }^{107}$ Pickles, 'Images of Landscape', 353.

${ }^{108}$ P. Joyce, ed., South Africa's Yesterdays (Cape Town, The Reader's Digest Association South Africa, 1981 ), 51.

${ }^{109}$ Markwick, 'Postcards from Malta', 419.

${ }^{110}$ Prochaska and Mendelson, 'Introduction', xiii; Corkery and Bailey, 'Lobster is Big', 492.

${ }^{111}$ Foster, Washed with Sun, 17, 58.

${ }^{112}$ M. Pretes, 'Tourism and Nationalism', Annals of Tourism Research, 30, 1 (2003), 127; N. Coetzer, 'A Common Heritage / An Appropriated History: The Cape Dutch Preservation and Revival Movement as Nation and Empire Builder', South African Journal of Art History, 22, 2 (2007), 174.

${ }^{113}$ THL, Annual Report, 1935, 76.
} 


\section{The world of 'technology and progress'}

The postcards in this cluster deal mainly with the promotion of the SAR as a corporation and give an overview of its activities in terms of road, rail and air transport systems. The ideological propositions that underlie this are related to the discourse of technology, modernity, and progress, as indicated previously. Meikle observes that the Teich postcards celebrate modernity through the representation of roads, bridges, dams and industrial facilities, betokening a glorious future 'through technological progress. ${ }^{114}$ This tendency is equally observable in the SAR postcards -36 of them show cities, industries and dams, with an emphasis on dramatic skylines and cities shimmering at night. It is fitting that Johannesburg, as the 'endpoint of economic progress $^{115}$ and the modern city of gold, features in the majority of the postcards, displaying its brash pride in industrialism and progress.

Nonetheless, the majority of the postcards (145) that epitomize modernity and progress deal directly with the SAR. This is appropriate, as the formation of the centralized SAR in 1910 was intimately linked with the expansion of the mines and agriculture and ushered in the processes of urbanization and industrialization that made the Rand the economic hub of South Africa. ${ }^{116}$ The SAR played a very complex role, both social and economic; its railway system linked the mines and related industries on the Highveld with the coastal harbours, signifying modernity, but at the same time this system made possible new forms of leisure and travel that expanded the horizons of South African citizens. The Western metanarrative of modernity was connected with technology, and created a narrative wherein trade and cooperation became hallmarks of civilization. ${ }^{117}$ The SAR illustrated the material advantages of capitalism (and, to a lesser extent, imperialism) and became 'an iconographic symbol of the progressive white state ... overcoming

\footnotetext{
${ }^{114}$ Meikle, 'A Paper Atlantis', 274-275.

${ }^{115}$ Foster, Washed with Sun, 214.

${ }^{116}$ Foster, Washed with Sun, 34-36.

${ }^{117}$ Coe, 'Histories of Empire', 7.
} 
practical and ideological opposition to modernization in backcountry areas. ${ }^{118}$ The SAR was an instrument of social change and reconstruction, helping to promote a common white identity based on the imperatives of modernity; photography and the railways, as joint icons of modernity, worked in tandem to advance modernization and nation building. ${ }^{119}$ Although this nation-building imperative was certainly different in the second half of the twentieth century, the SAR was still able to harness and manipulate images that served the needs of the new Republic.

The first group of postcards deals with SAR station buildings, but also deals with the social face of the Corporation. The majority of the images (17) therefore feature satisfied clients enjoying their journeys on the luxurious Blue Train, Drakensberg Express and the Trans Karoo. They are shown in relaxed circumstances, eating, drinking and socializing, and the emphasis falls on culinary excellence and exceptional service (fig 8). They seem to avow the same class position and are all white - even the bartenders and waiters are exclusively white. Two similar postcards show well-off diners in the prestigious Blue Room Restaurant and Bar in the old Johannesburg Station building. The rest of the postcards show various SAR stations buildings, principally the new Johannesburg Station (as another signifier of modernization) and scenes depicting white people making travel bookings in SAR travel offices. These postcards also continue the narrative of leisure time and affluence discussed under the 'world of culture' above; the trains depicted are luxury overnight trains, not short haul (sub)urban or commuter trains, and thereby support the connotations of wealth and travel for recreation rather than work purposes.

\footnotetext{
${ }^{118}$ Foster, Washed with Sun, 203; Foster, 'Land of Contrasts', 661. This was particularly important in establishing modern forms of agriculture, and here the SAR again played a key role by commissioning documentary films that championed new methods and at the same time, 'promoted a modernised Afrikaner national identity.' Sandon, 'Preserving a Heritage', 60.

${ }^{119}$ Foster, 'Land of Contrasts', 660.
} 


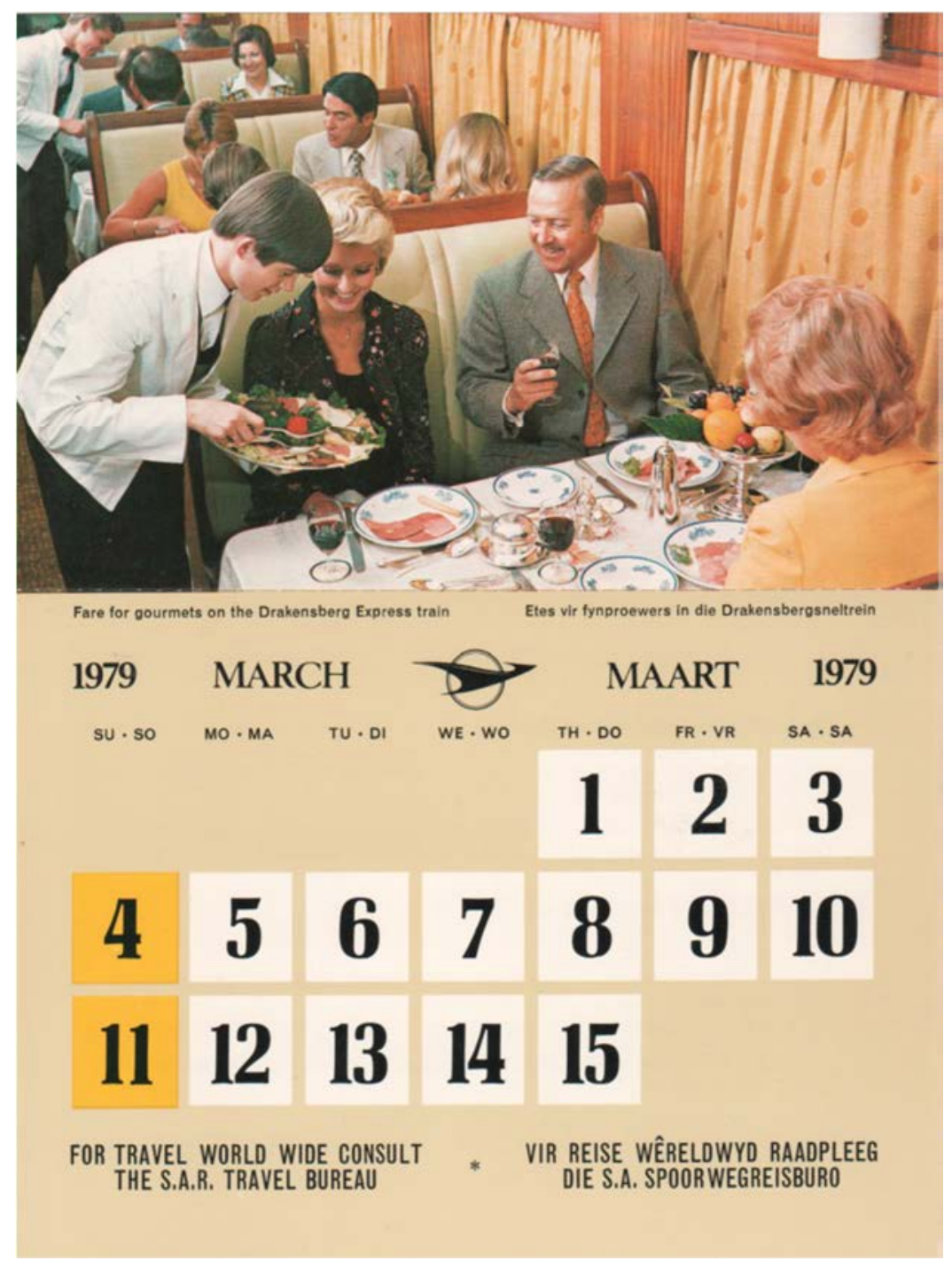

Fig. 8. 'Fare for gourmets on the Drakensberg Express train'. SAR postcard, 1979. Courtesy of Transnet Heritage Library.

The last postcards show the workings of the SAR: its trains, motor coaches, harbours, airplanes, heavy road transport, and lighthouses. The trains (28) shown here hurtle through various South African landscapes; ${ }^{120}$ nine of them are steam-driven, and luxury passenger trains are counterbalanced by a few goods trains (fig 1), which are seemingly indicative of a thriving economy. It was previously mentioned that the SAR motor coaches played an important role in supplementing train services. The first road service dates from December 1912 and linked the station at Bot River with the village of Hermanus in order to develop it 'as a holiday and seaside

\footnotetext{
${ }^{120}$ These images are typical of earlier SAR iconic images of trains winding their way north through the Cape mountains. Foster, 'Northward, Upward', 311, 315 note 86. See also note 3 above.
} 
resort. ${ }^{121}$ Motor coach tours were still attracting more than 32,000 people in 1982, but by 1987 efforts 'to penetrate the local market ... [did] not live up to expectations'. ${ }^{122}$ The 27 postcards that depict motor coaches are shown as a vehicle towards leisure and tourism at places such as the Drakensberg, and when people are shown, they are again exclusively white. The harbours (27) include all the major docks in South Africa and attempt to convey the image of a vibrant economy, which is of course at odds with the reality of the situation during the 1970s and 1980s when international boycotts severely curtailed harbour traffic to South Africa. Ten postcards dealing with the SAR road transport service mainly depict abnormal loads in transit, and 18 postcards show various South African Airways airliners, from a Boeing 707 (1966) to an Airbus A300 (1982). The narrative is again one of being up-to-date in terms of technology and offering the best to SAR clients. This cluster ends with three postcards of lighthouses around the South African coastline.

\section{Conclusion}

I have suggested in this article that the SAR played a significant role in creating a positive view of South Africa from 1910 onwards and that this continued into the second half of the twentieth century. In this respect, the SAR was part of a wider network of corporations and governmental organisations that generated an official discourse about South Africa. Albers and James note that it is important to establish who produced the postcards, in what context, for what market, and to ask whose ideological interests they served. ${ }^{123}$ The discussions above established that the SAR was the sole producer of the postcards and that they were intended primarily as promotional

\footnotetext{
${ }^{121}$ A Century of Transport, 72.

${ }^{122}$ THL, Annual Report, 1982-1983, 23; THL, Annual Report, 1986-1987, 31.

${ }^{123}$ Albers and James, 'Travel Photography', 138, 150-151. Even though contemporary commercial postcard ranges such as those produced by Artco, Art Publishers, and Protea Colour Prints seem to have generated very similar images of South Africa, the SAR calendar postcards were different in that individual postcards could not be selected and bought.
} 
material and for the tourism sector. As intimated previously, the conservative and unchanging nature of the postcards suggests that this was an homogenous market that required familiar or conventional images that did not disrupt its sense of complacency. Not surprisingly, postcards have always been associated with nationalistic self-promotion and propaganda and generally reflect the preferences and views of those who purchase them. ${ }^{124}$

In order to draw definitive conclusions about the ideological narrative constructed by the SAR postcards, it would be necessary to have a complete data set for a longitudinal study. The only two years that are complete, with 24 postcards, are 1980 and 1984, and the records for the early 1960s are very fragmentary. Nonetheless, an interesting tendency can be observed by comparing 1966 (15 postcards) with 1980 and 1984. In the earlier years, leisure activities and spacious landscapes seem to have been given precedence, whereas in 1980, 14 postcards depicted the world of technology, mainly SAR-related, and in 1984, this had risen to 18 . This may be indicative of a growing emphasis by the SAR on promoting its own activities, rather than publicizing the country, as well as a growing emphasis on domestic tourism. It could also be read as an attempt to demonstrate that South Africa was economically strong, despite the international boycotts.

From the early decades of the twentieth century, it was imperative for South Africa to position itself as a metropolitan, modern country in order to offset implied backwardness. ${ }^{125}$ The oscillation between characterizing the country as sophisticated but at the same time as part of 'primitive' Africa, underlay most of the material directed at tourists, reassuring them of the presence of Western luxuries and infrastructure. This need to modernize was paradoxically

\footnotetext{
${ }^{124}$ Schor, 'CartesPostales', 213; Jokela and Raento, 'Collecting Visual Materials', 54, 57.

${ }^{125}$ Rassool and Witz, 'South Africa', 359.
} 
accompanied by the rise of nostalgia for premodern experiences, ${ }^{126}$ probably exemplified best by a retreat to nature. The official metanarrative produced by powerful bodies such as the SAR during the second half of the twentieth century did not necessarily produce explicit propaganda for the government, but did attempt to 'direct the tourist gaze' and create a 'positive' view of South Africa. ${ }^{127}$ According to Groenewald, the magazine Panorama failed 'to contextualise their relentlessly positive reportage, and [were] selective in their portrayal of cultural experiences within South Africa', ${ }^{128}$ and the same can be stated about the concurrent SAR postcards. They represent an idealized and unchanging image of the past and of a glowing future, directed by the imperatives of modernization, but neglect to engage with current realities. ${ }^{129}$ So, for example, the gradual rise in black tourism in South Africa from the beginning of the $1980 \mathrm{~s}^{130}$ does not manifest at all in the SAR postcards. It can thus be suggested that the SAR's own history and apartheid ideology predictably informed the production of these postcards that 'show the skyscrapers and the prosperity of Johannesburg and Pretoria, but not those who built them. ${ }^{131}$

\footnotetext{
${ }^{126}$ Foster, Washed with Sun, 39-40.

${ }^{127}$ Grundlingh, 'Revisiting', 108-109.

${ }^{128}$ Groenewald, 'Cloudless Skies', 61-62.

${ }^{129}$ South Africa has now become a destination for new kinds of tourism such as 'dark tourism' that focuses on sites where resistance to apartheid, punishment and incarceration took place. Visser andRogerson, 'Researching the South African', 204. This has led to the rise of postcards that depict places such as Robben Island as well as formerly taboo scenes such as township life.

${ }^{130}$ Rogerson and Lisa, “'Shot't Left', 101); Ferrario, 'Emerging Leisure Market', 23-38.

${ }^{131}$ Nederven Pieterse, White on Black, 107.
} 